How to cite this article:

Barizah, N. (2020). Reviewing international patent policy on biotechnological inventions and the adequacy of the equitable benefit sharing principle. UUM Journal of Legal Studies, 11(2), 203-224. https://doi.org/10.32890/ uumjls.11.2.2020.8696

\title{
REVIEWING INTERNATIONAL PATENT POLICY ON BIOTECHNOLOGICAL INVENTIONS AND THE ADEQUACY OF THE EQUITABLE BENEFIT SHARING PRINCIPLE
}

\author{
Nurul Barizah \\ Department of International Law, \\ Faculty of Law Universitas Airlangga, Indonesia \\ nurul.barizah@fh.unair.ac.id
}

Received: 10/2/2020 Revised: 7/6/2020 Accepted: 14/6/2020 Published: 31/7/2020

\begin{abstract}
The purpose of this study is to review the international patent policy related to biotechnological inventions, particularly from the Venetian Patent Law to the TRIPS Agreement. It closely examines whether such inventions fulfill the patentability thresholds and analyses the reason why such patents are regarded as having the potential to cause facility misappropriation of biodiversity, which is considered unfair. The most important part of this study is the adequacy analysis of the principles of equitable benefit sharing of the Convention on Biodiversity (CBD), including disclosure requirements and prior informed consent (PIC), to prevent misappropriation of biological resources in this era of the fourth industrial revolution. This study is based on the normative legal research method and uses primary and secondary legal resources. The analysis conducted for this study employed several approaches, which were statute, conceptual, and historical approaches. This study found that patent protection for biotechnological inventions has received justification since the Paris Convention. However, the current international patent policy has the potential to facilitate misappropriation of biodiversity203d it is
\end{abstract}


regarded as unfair. On the other hand, the equitable benefit sharing principle is still inadequate in dealing with such misappropriation. It advises the requirement of mandatory disclosure of origin to be regulated under national law as a legal basis for implementing the equitable benefit sharing principle.

Keywords: Patent policy, Venetian Patent, TRIPs Agreement, biotechnological inventions, equitable- benefit sharing.

\section{INTRODUCTION}

Modern biotechnology industries still play a prominent role in this fourth Industrial Revolution (Lorenzo, 2018). The scopes of these industries are very advanced, covering inventions related to genetic resources, such as gene sequencing, microorganisms, biogenome and many others (Bhatia, 2018). Such industries usually use biological resources as basic raw materials (Prestre, 2017; Fisher III, 2001) and because of that, biological resources are regarded as one of the most important commodities in this era. The advancement and evolvement of biotechnology industries in the developed world are driven by the strong protection of the intellectual property rights (IPR) regime, particularly patent (NS, 2008; Kunin et al., n.d.). Although in early history, patent policy did not provide protection to living things (May \& Sell, 2006), this policy is changing along with the massive development of modern biotechnology (McKeough et al., 2007).

In 1994, the Trade Related Aspects of Intellectual Property Rights (TRIPs) Agreement of the World Trade Organization (WTO) laid the legal foundation for the protection of inventions in all areas of technology without discrimination, including inventions related to life forms and other genetic resources. This policy, as observed by many scholars, has the potential to facilitate misappropriation of biodiversity derived from developing countries (Ho, 2006; Rabitz, 2015). This has placed developing countries, which are rich in biological resources, at disadvantage because the IPR system particularly in the context of biological resources has not benefited them as the owners of such resources. William Fisher states that the current IPR regime has become the main vehicle for corporations to develop new medicines and plant varieties, but the countries from 
which the samples used to produce those medicines and varieties are taken do not receive any protection (Fisher III, 2001). Meanwhile, under the IPR law, owners and inventors of protected or patented works have a right to receive the benefit or compensation from the use or exploitation of their works as stipulated in the Universal Declaration of Human Rights, Article 27 (Wahid e.al., 2019).

In 1992, at the United Nations Conference on Environment and Development, in Rio de Janeiro, the Prime Minister of Malaysia expressed this concern by stating that;

"The poor countries have been told to preserve their genetic resources on the off-chance that at the some future date something is discovered which might prove useful to humanity... We are also told that the rich will not agree to compensate the poor for their sacrifices. The poor are not asking for charity. When the rich chopped down their forests... and scoured the world for cheaper resources, the poor said nothing. Indeed, they paid for the development of the rich. Now the rich claim a right to regulate the development of the poor countries. And yet any suggestion that the rich compensate the poor adequately is regarded as outrageous. As colonies, we were exploited. Now, as independent nations, we are to be equally exploited."

The statement indicates a great concern related to the global regime of IPR protection related to biological resources, which potentially facilitate misappropriation of biological resources from developing countries.

The international patent policy under the TRIPs Agreement is technologically neutral. It provides protection to all types of inventions without discrimination, including biotechnological inventions derived from genetic resources. On the other hand, the international legal system provided by the CBD and Nagoya Protocol as a measure to ensure fairness of the utilization of biological resources is not part of the IPR system. It is not easy for disclosure requirements of the country of origin of the biological resources as a basis for granting patent rights to receive international acceptability. 
Based on the above background, this study analyzed the international patent policy dealing with biotechnological inventions, from early history under the Venetian Patent Law, Paris Convention to the TRIPs Agreement to find out the justification of such protection. It also analyzed whether biotechnological inventions fulfill the patentability thresholds provided by the TRIPs Agreement. Further, the research examined whether international patent policy potentially facilitates misappropriation of genetic resources, how to address it, and how to accommodate the balance in the interest of both the biotechnologically -rich developed nations and the biodiversity- rich developing nations. This study further analyzed the adequacy of the fair and equitable benefitsharing principles of the CBD and Nagoya Protocol to prevent misappropriation of biological resources and to provide a sense of justice from the use of the biological resources of developing countries in this fourth industrial revolution era. Lastly, it offered a solution to prevent misappropriation of biological resources.

\section{METHODOLOGY}

This study employed the normative legal research method. Research data were obtained from primary and secondary resources. The analysis of this study used the : statute, conceptual, and historical approaches. The legal materials used for this study were divided into primary and secondary legal materials. The primary legal materials consisted of conventions, treaties, protocols and national laws relevant to this study. Meanwhile, the secondary legal materials were obtained from books on law related to this topic, journal articles and many others. All the above legal materials and resources were then analyzed by using the above approaches.

\section{RESULT AND DISCUSSION}

\section{International Atent Olicy Related to Iological Esources; fFrom Arly Istory to TRIPs Agreement}

In the early history of the patent law in Venice and England, most patent grants were made for mechanical inventions. For instance, 
fifty years prior to the Venetian Statute of 1474, the Florentine authorities awarded a patent-like grant to Brunellischi for a new vessel design used for moving loads more cheaply along the Arno River. In 1440, a patent was granted to John Shisedame for introducing a new process of salt manufacturing in England. In 1449, John Utynam returned from Flanders bringing with him a new method for producing colored glass from which he gained a monopoly (or patent). Frank Prager identified certain grants of privilege during the Middle Ages as 'quasi-patents' covering mining operations, various water systems, and other commercial activities (May \& Sell, 2006). In 1598, Edward Darcy was granted a letter patent for playing cards (McKeough etal., 2007). In 1565, the first English patent was granted to the invention of a new type of furnace (Grubb, 2004). At that time, there were no initiatives for protection of living things. Merger and Ginsburg argued that natural phenomena, discovery, metal process, and intellectual concept (abstract) cannot be patented (Merges \& Ginsburg, 2004). The reason for such unpatentability is because they are regarded as basic tools for scientific and technological works (Merges \& Ginsburg, 2004).

The first substantive patent statute, the Venetian Patent Statute of 19 March 1474, is regarded as the origin of the modern substantive patent law (Mgbeoji, 2003) and procedure. It does not clearly specify the types of invention subject to patent protection. However, evidence has shown that, at that time, the subject of protection was greatly dominated by, if not totally limited to, mechanical inventions and artifices (Reichman, 1994). By the end of the nineteenth century, the substantive principles of patent law were established. One of the most generally accepted principles was that mere ideas and discoveries of natural phenomena were disqualified from patentability, although at this time, there was no obvious legal interpretation of the term 'invention' and 'manufacture' (Mgbeoji, 2003). Subsequently, a patent law evolved, and eventually had an effect on the clarity and integrity of the Venetian patent system (Mgbeoji, 2006).

Then, in 1883, the Paris Convention established an international union for the protection of industrial property. Mgbeoji noted that the internationalization of patent laws started almost at the same time as the patent concept itself, and under this Convention, the concept of a patent underwent a phase of theoretical and juridical development 
(Mgbeoji, 2006). However, the Paris Convention does not provide any definition of 'invention' or 'patentable subject matter'. In accordance with its name, it provides a general perspective and focus on rights described as 'industrial property' which may provide some directions when trying to understand what was then understood to underlie the patent system in, or that should be in, Member Countries. Under the Paris Convention, Article 1(3), the meaning of 'industrial property' is very broad, as it is not only applied to industry and commerce, but also to agricultural and extractive industries. This Article 1(3) also covers all manufactured or natural products, such as wines, grain, tobacco leaf, cattle, mineral water, beer, flowers and flour.

In reading Article 1 (3) of the Paris Convention above, Article 1 (4) of the Convention should also be read. This Article 1 (4) stipulates that;

"Patent shall include the various kinds of industrial patents recognized by the laws of the countries of the Union such as patents of importation, patents of improvement, patents and certificates of addition, etc."

Thus, the determination of what constitutes as patentable subject matters depends very much on each Member nation. However, it important to note that Article 1 (3) above recommends Member nations to adopt a wide flexible approach including agricultural, natural products and living materials, as Article 1 (3) explains that those products and materials fall within the industrial property scope.

Based on the above Article, the subject matters of a patent could be considered to have been expanded by incorporating natural products and life forms, like animals and plants. This article supports the argument that the broadest concept of industrial property has received legal recognition since the establishment of this Convention. If industrial property is to be defined in this way, covering agriculture and all manufactured or natural products, a patent as part of industrial property should be similarly understood mutatis mutandi. 
Although based on a traditionally accepted principle of the patent law, life forms were disqualified from patentability (Palombi, 2004), the interpretation of industrial property under the Paris Convention can be regarded as providing basis for the protection of natural products and life forms. This Paris Convention entered into force in 1970. After that, patent protection has been granted to some parts of life forms. For example, in 1975, the German Federal Supreme Court declared that micro-organisms are patentable. In 1980, Diamond $v$. Chakrabarty affirmed that micro-organisms are patentable in the US, while in 1985, the US PTO appeals board decided that plants, seeds and plant tissue cultures are patentable. In 1987, the US PTO announced that multicellular organisms are patentable. In 1988, EPO granted the first patent for plants and the US PTO issued a patent for oncomouse.

Then, in 1994, the TRIPs Agreement was concluded as part of the establishment of the World Trade Organization (WTO). This Agreement is an important legal document dealing with international IPR protection. The TRIPs Agreement has revolutionized patent law because its provisions embody a set of basic norms that go much beyond those contained in the Paris Convention and in other international agreements. The TRIPs Agreement significantly extended the standard of patent rights internationally and required the enforcement of patent standards in the international arena among the WTO Members.

Article 27 (1) of this TRIPs Agreement is the most far-reaching and stringent provision concerning patent law standards. This Article deals with patentable subject matters and provides that patents shall be granted to inventions, not discovery, in the form of all new and useful products and processes in all areas of technology without discrimination. The wide coverage of Article 27 (1) is to ensure that no material will be excluded from a patent law, including biological resources. In designing the national patent law, member nations should not only refer to Article 27 (1) of the TRIPs Agreement, but should also use the flexibility provided by the Agreement, including the level of economic and technological development (Shanmugaiah, 2012). Furthermore, Article 27 (3) b also requires Member nations to grant patents to micro-organisms and non-biological and microbiological processes. Members are also required to provide plant varieties 
protection by a patent or by the sui generis system as long as it is effective, or by a combination of both. Accordingly, Article 27 of the TRIPs Agreement provides a legal basis for patent protection related to biological resources, including genetic resources related to traditional knowledge (GRTK).

After that, the 1995 European Patent Office (EPO) declared that DNA is not life, but a chemical substance which carries genetic information and therefore constitutes patentable subject matters. Such protection is in line with the development of modern biotechnology industries, particularly recombinant DNA technologies, which use genetic resources, including human genetic resources as the main ingredient or raw material for such biotechnology.

\section{Patentability of Iotechnological Nventions, Including Genetic Resources Related to Traditional Knowledge}

After patent protection to biotechnological inventions under the TRIPs Agreement, including Genetic Resources Related to Traditional Knowledge (GRTK), had been provided, the next question was how such inventions fit into the notion of a patent law in general, and how they satisfy the patentability thresholds, particularly novelty and inventive step requirements. Because of that, it was important to analyze whether genetic resource-based inventions satisfy the above requirements based on patent law principles. This part also analyzed the reason why the patentability of such inventions is regarded as having the potential to facilitate misappropriation of biodiversity, including genetic resources.

The first patentability threshold is novelty. In general, the standard used to determine novelty is to test against the State of the Art or Prior Art Base. In practice, the prior art test can be divided into three categories. The first is domestic novelty test; the second is worldwide novelty test; and the last is mixed novelty test. Domestic novelty test implements a very limited concept of prior art, in which the state of the art is limited to a discussion in the domestic jurisdiction even if known in other jurisdictions. Consequently, inventions which are part of the public domain in other countries may be patentable in a country which employs such a test. A mixed prior art base test means that the state of the art includes inventions and information 
in written publications anywhere in the world. One interpretation of this test is that oral information or unwritten knowledge, like traditional knowledge of certain communities, will not be deemed as prior art except in writing or printing.

It means that both of the above approaches or tests have opened the possibility of granting patents from the traditional knowledge developed by the local community of developing countries. These two tests also have the potential to facilitate misappropriation of GRTK of developing countries. The last is a world-wide prior art test. This test is not only against domestic inventions but also inventions and information available to the public everywhere in the world regardless of the form of information. This boarder approach to novelty testing has a significant role in restricting patents over GRTK because such GRTK can be regarded as part of the prior art base, so it cannot be patented. This approach can prevent an unfair misappropriation of biological resources. However, only a few countries apply this approach.

According to Correa, the novelty test means the claimed inventions shall be new in absolute terms and shall not have been a piece of the prior art anywhere in the world before the patent application date (Correa, 2000). In this context, Correa adopted a world-wide prior art test. Based on this criterion, traditional technological innovations fail to be protected under the patent law because these types of technologies are often passed through generations, thus losing their novelty. The technologies should become part of the public domain (Correa, 2000).

The second patentability threshold is the inventive step or nonobvious. As with novelty, there is no universal test to determine an inventive step of invention. Most jurisdictions usually apply one of the two types of inventive step test. The first is to ask whether the invention is obvious to a person skilled in the art. The other one is sometimes called the problem solution approach. In the context of biological inventions, the core of the question is whether isolated or purified genetic resources can be considered an inventive step or non-obvious to a person skilled in the art. There are two approaches which can be used to answer this question. The first approach strongly argues that there is no inventive step in the isolation of 
genetic materials, but the second approach argues that an inventive step is required to isolate genetic materials. The EPO considers that isolation of genetic sequence is inadequate to meet the inventive step requirement (Correa, 2000). The Myriad Genetic on the BRCA1 and 2 breast cancer genes patent was revoked mainly due to the lack of an inventive step (Correa, 2000). In contrast, the standard of the nonobviousness test in the US is very low compared to that in Europe. Isolating a genetic sequence may be regarded as non-obvious even when the prior art discloses the structure of the protein of the claimed gene and the general methods used for such isolation. Meanwhile, in Australia, IP Australia takes the view that in order to meet the inventive step assessment, biological materials -related inventions must involve "the technical intervention of a technologist applying their inventive ingenuity to produce something distinguishable from natural source material" (IP Australia, 2003). It means that each jurisdiction applies different standards to test the inventive step. However, based on the above approaches, it is uneasy for genetic resources- based invention, including GRTK to fulfill the criteria of inventiveness.

Although, patent on genetic resources- based inventions, including GRTK, may fulfill the third criteria of patentability threshold, that is industrial applicability, it is difficult for such inventions to meet the first two requirements of patentability, that are novelty and inventive step. Accordingly, the validity of such patents is in question. Those are the reasons why such patents are regarded as having the potential to facilitate misappropriation of biological resources of developing countries, without disclosure requirement, and fair and equitable benefit sharing given to the country of origin and the community who has conserved such resources from generation to generation.

\section{International Patent Policy on Iotechnological Nventions: Misappropriation of Iological Esources and Nfairness}

In practice, there are two types of patents involving genetic resources. The first is direct patenting of source materials, in which a patent directly claims genetic resources obtained from separate sources as an invention. The second is patenting of an invention which is derived from source materials, or somehow uses genetic resources (WIPO, 2004). Such practices have extended the patentable subject 
matter and opened possibilities to grant patents on inventions which do not meet the patentability thresholds as mentioned earlier. Such practices are of concern because they openly use genetic resources that amount to improper or unfair misappropriation of the resources. This is serious and, particularly unfair, where a patent permits a misappropriation of GTRK by biotechnology industries or other commercial entities (Mcmanis, 2004). McCall argues that "patenting biological substances is a mistake, both morally and economically, for any system of intellectual property and should be reanalyzed at all levels, particularly as it affects developing nations" (McCall, 2003).

Similarly, Mgbeoji (2006) explicitly claims that patent policy facilitates global biopiracy. Scholars like Drahos ( 2005), Blakeney (2004), Dutfied (2000), Andews ( 2002), Maskus and Reichman (2005), Ullrich (2005), Aoki (2003) and many others also express similar concerns. In general, they argue that the expansion of the subject matters of the IPR particularly to include biological resources, including life forms, might facilitate biopiracy of developing countries' resources. Such a condition can potentially affect the availability of public goods on the basis that those important resources can be privatized under a global IPR framework by biotechnologyindustrialized countries. Martin Khor also argues that the large scale patent granting for genes and other biological materials leads to an even greater concentration of control over the world's food crop by a few corporations (Khor, 2002). According to Khor, these patents pose a threat to global food security, including farmers' livelihoods (Khor, 2002). Furthermore, Jeffery (2004) states that;

"Opponents to the pro-patent viewassert that by creating patents over living organisms we are encouraging the destruction of biodiversity and creating monopolies that are unfair and immoral. This view says that such patents also support 'biopiracy', which is unauthorized use of biological resources or the traditional knowledge held by indigenous communities or developing countries.".

Moreover, the patent system is also used as a means to transfer the benefits of genetic resources from the biodiversity- rich developing countries to the biotechnologically-rich developed countries. In this context, Mgbeoji (2006) illustrates that; 
"Today's pirates don't come with eye patches and daggers clenched in their teeth, but with sharp suits and claiming intellectual property rights. So those rich countries which take seeds away from their poorer neighbours and then try to patent them are guilty of theft - plain and simple; biopirates by another name."2006)

If intellectual property holders can commercialize the patented inventions and earn revenue on the basis of exclusive rights, the local communities or the countries that developed or used the knowledge or resources do not receive any revenue or benefit from the patent. This can be seen as unfairness. This condition is ironic if the patented inventions are relatively expensive to developing countries from which the patented process and products originated. Because of that, the patent system is regarded as one of the roots of unfairness in global wealth distribution. Patent law only protects inventions that satisfy the collective requirements of patentability, and such requirements in practice operate to eliminate the opportunity for traditional technological innovations to be protected under this system. Patent law provides protection for modern laboratory products and processes in pharmaceutical companies' inventions even though such inventions are derived from traditional medicinal knowledge of certain local communities.

This unfairness seems more blatant when the technological element to establish novelty or inventive step for the purpose of patent law is only a very thin veneer covering the traditional knowledge considered to be incapable of getting patent protection (Ho, 2006). In simple words, patent system facilitates the interests of technological innovations which take place in modern technological societies and fails to acknowledge the traditional systems of knowledge that have evolved over time in traditional societies .

Despite the problem of misappropriation, the extension of patentable subject matters to include genetic resources- based inventions and other life forms also leads to another critical problem. Llewelyn observed some critical problems in the patent system in relation to the principles of protectability, patentability, predictability and certainty, 
known as $P 3$ plus $C$ (The Nuffield Council on Bioethics, 2002). The root of the problem, according to Llewelyn, is the first two principles, which she regards as the basis of the current policy, while, she regards the last two principles as an effect of the application of the first two principles (Llewelyn, 1994). With respect to protectablity, Llewelyn observed that the patent system has been expanded, both in terms of use and types of protectable subject matters, to accommodate the widest scope of subject matters (Llewelyn, 1994). This expansion inevitably brings legal consequences to the difficulty of predicting potential inventions eligible for protection. The reflection of the expansion of the patent policy can obviously be seen in three aspects, which are the patentability thresholds, the nature of subject matters excluded from patentability categories, and the scope of the exclusive right given. This can be seen in the TRIPs Agreement and the practices in several most influential jurisdictions.

Accordingly, patent granting related to genetic resources not only continues to face theoretical difficulties and facilitates biopiracy, but also leads to the principles of protectability, patentability, predictability and certainty of the modern patent system being in question. A shortage of patent examiners and a huge number of applications have also created backlogs of examination and this leads to the pending of the patent right being granted. As a result, the modern patent system faces an acute problem of maintaining acceptable quality and overall integrity.

\section{The Dequacy of Prior Informed Consent (PIC), Isclosure of Rigin, and Quitable Enefit- Haring Rinciples of the CBD to Revent Nfairness}

Historically, the PIC principle is rooted in multiple disciplines and social contexts, including those in the health profession, law, moral philosophy, and social and behavior sciences. This principle extends increasingly to include IPR, especially when the protected right makes use of biological resources derived from a certain traditional community's knowledge. Article 5 of the CBD has an influential role in providing a legal basis for PIC for the purpose of access to and the use of traditional knowledge, innovations and practices relating to biological resources. This principle then becomes very relevant to intellectual property since Paragraph 19 of the Doha Ministerial 
Declaration instructs the Council for TRIPs, in its review of Article 27.3(b) and Article 71.1 to consider the relationship between TRIPs Agreement and CBD, in which one of the key provisions is PIC.

PIC is an essential principle in international relations as a manifestation of a state's permanent sovereignty over its natural resources, as stipulated in Article 3 of the CBD. In the light of biological resources access, this principle is also very important due to the practice of misappropriation. However, it is noteworthy that PIC alone is insufficient to prevent such misappropriation. This principle, in the context of access to biological resources, focuses only on preventing exploitation and movement of potentially beneficial resources from the country of origin, and, in particular, ensuring that the benefits derived from the use of such resources are fairly distributed to the provider country (Perrault \& Olivia, 2005).

In 2002, the Bonn Guidelines on Access to Genetic Resources and Fair and Equitable Sharing of the Benefit Arising out of their Utilization was established for the purpose of assisting the parties and stakeholders in implementing the principle of PIC in relation to access to biological resources and benefit sharing. These guidelines provide the basic principles of the PIC system in general and address certain steps in the process of access and benefit sharing in particular. Article 31 of these Guidelines states that the consents of relevant stakeholders such as the indigenous and local communities are required and such a requirement is subject to domestic law. Then, consent of relevant competent national authorities in the provider country is required for ex situ collections. This principle has been established in several countries as a condition of access to GRTK such as in Venezuela, Philippines, Peru, Panama and the Andean Community. The difficulty is that there is no internationally legal binding instrument which obliges all the WTO member nations to implement PIC in their national patent law.

Then, in 2010, the Nagoya Protocol on Access to Genetic Resources and the Fair and Equitable Sharing of Benefits Arising from their Utilization to the Convention of Biodiversity was adopted (Nagoya Protocol). In the context of access, Article 6 of this Protocol emphasizes that access is subject to PIC and because of that, provider countries shall provide national access and benefit sharing 
(ABS) legislation. Substantially, this National ABS legislation shall provide three aspects: (a) "legal certainty, clarity, and transparency"; (b) procedures and rules on access in fair and non-arbitrary; and (c) clear and cost-effective information on the procedure for applying PIC, including the procedure if the access involves local communities (Kamau et al., 2010). Article 5 of this Protocol regulates benefit sharing, which obligates each party to provide legislative, administrative, or policy to ensure that benefits arising from the use of genetic resources are shared in fair and equitable manners. The exact term of fair and equitable benefit sharing is not defined under the Protocol (Najar, 2011); there is no sufficient definition of benefit sharing. However, there are several approaches and options which can be used by countries in the implementation of such a principle based on the principle of justice (Najar, 2011; Medaglia et al., 2012; Jonge, 2011).

In order to implement the $\mathrm{CBD}$ and Nagoya Protocol, many countries have issued national legislations on ABS ( Medaglia et al., 2012), but there are also many countries which have not issued such legislation. The model of the ABS rules of each county is also different, and the effectiveness of such legislation is also still in question (Pauchard, 2017). Based on the above condition, Muller suggests that to support the implementation of $\mathrm{ABS}$ at the national level, a new international regime might be needed (Muller, 2018). Without the international regime of ABS, it is uneasy to eliminate the problem of misappropriation of biological resources.

Besides PIC and ABS, disclosure of origin is also considered as a legal mechanism to prevent misappropriation. The scope of disclosure of origin has achieved a consensus. It can be defined as country of origin, country providing biological materials, origin of genetic resources, source and country of origin, sources of any biological material, geographic origin, source of origin, source of a specific genetic resource, and so forth (Correa, 2003).

The functions of the disclosure of origin, as indicated by the CBD are; firstly, for transparency, that is to disclose any biological resources used in the course of developing an invention; secondly, for the disclosure of origin, that is to disclose the actual source of biological resources; and thirdly, for compliance, that is to provide 
an undertaking or evidence of PIC. At the moment, the development of this discourse at the TRIPs Council, World Intellectual Property Organization (WIPO), and Conference of the Parties (COP) to the CBD is still being examined; what are the appropriate approaches to implement this principle into national and regional IP laws, including access to benefit sharing regulations? In fact, several national and regional jurisdictions have applied this measure, although discussions on the disclosure of origin are still ongoing in a number of international forums. Amongst the nations which have adopted the principle, the level of protection can be categorized into weak, medium and strong disclosure options.

Consensus on the legal and administrative nature of making it a requirement of valid patent applications has not been reached. The only achievement of those forums was identification of the types of disclosure, but it is still subject to intense discussions until now, as to which type is the most satisfactory. Dutfield identified three types of disclosures, which are voluntary disclosure; mandatory disclosure and proof of legal acquisition (Dutfield, 2005). Voluntary disclosure will not have a significant effect and legal consequences for its omission of this disclosure, and because of that, it is unable to disqualify the patent granted. Meanwhile, under this mandatory disclosure, failure to disclose has a legal consequence of rejection of the patent application, and if the patent has been granted, it would not be enforceable or revoked with the possibility of criminal sanction

To some extent, according to Dutfield, the proof of legal acquisition is the most useful approach on three grounds. First, it will produce a modest outcome in terms of improving patent quality and preventing unauthorized appropriation and commercialization of biodiversity. Second, it will not infringe the TRIPs agreement as long as it is implemented as an administrative measure. Third, this approach will avoid philosophical and technical difficulties (Dutfield, 2005). However, as stated earlier, this proof of legal acquisition will not prevent all acts of misappropriation of GRTK. Rather, it is no more than a means of achieving technological capacity- building, improvement of national and local economy and poverty alleviation.

In relation to the nature of the disclosure of origin, there is an idea that the requirement of disclosure of origin on patent application 
shall not affect the validity of the patent, but the failure to fulfill the requirement of the disclosure of origin should constitute fraud. However, it is unclear whether national patent laws provide remedies for such an abuse of rights. The Australian Patent Act for example, has a provision allowing revocation where the patent or an amendment to the request or specification is obtained or made on a misrepresentation or by fraud under Section 138 (3). However, it is still unclear whether this provision will cover fraud due to failure to disclose the origin of biological materials.

In considering the benefit of the sharing principle, Baer argued that the Rawlsian theory of distributive justice may be important in the discussion of the ethics of intellectual property in relation to the CBD. According to Baer (1995), this theory formulates the priority rules as follows;

"There are two cases: (a) an inequality of opportunity must enhance the opportunities of those with the lesser opportunity; (b) an excessive rate of saving must on balance mitigate the burden of those bearing this hardship."

Baer argued that this theory, together with the Hohfeldian analysis, highlights the duties that "go along with the rights of corporations with regard to the societies in which these corporations exercise their activities" are applied in the CBD. Rawls and Holfeld's view requires that capital gained from IPR be invested in the protection of biological resources in the countries from which the resources are derived (Baer, 1995). Those views adopted in the Preamble and several provisions of the $\mathrm{CBD}$ require each contracting party to share the result of $R \& D$ and benefits arising from the use of genetic resources in a fair and equitable way as provided under Article 15.

\section{CONCLUSION}

This study concludes that patent protection for biotechnological invention has received justification since the Paris Convention. TRIPs Agreement provides a legal basis for the protection of microorganism, non-biological and microbiological processes. This 
patent related to biological resources goes beyond the traditional foundation of patent law and it does not easily satisfy the patentability thresholds of novelty and inventive step. Patent granting related to genetic resources not only continues to face theoretical difficulties and facilitate misappropriation of biodiversity, but also leads to the principles of protectability, patentability, predictability and certainty of the modern patent system in question. Because of that, the modern patent system faces an acute problem of maintaining acceptable quality and overall integrity.

Patent policy under the TRIPs Agreement is considered inadequate in dealing with the protection of developing countries' interest on biological resources. The extension of patentable subject matters to include biological resources- based inventions is regarded as unfair, while the international patent policy does not provide measure to balance the interest of both the biotechnologically- rich developed nations and the biodiversity- rich developing nations. On the other hand, PIC and ABS as mandated by the CBD, Bonn Guidelines and Nagoya Protocol are still facing challenges in their implementation at the national legislation level in the absence of an international regime as each country has its own rules. Accordingly, they lack adequacy in dealing with misappropriation of biological resources. It is also uneasy to insert the disclosure of origin into the national patent law because such disclosure is not part of the IP system. This study suggests that mandatory disclosure of origin needs to be regulated under the national patent law and this type of disclosure is the basis for implementing fair and equitable benefit- sharing.

\section{REFERENCES}

Andrews, L. B. (2002). Genes and patent policy: Rethinking intellectual property rights. Nature Reviews Genetics, 10(3), 803-808.

Aoki, K. (2003). Traditional knowledge, intellectual property, and indigenous culture; article: weeds, seeds \& deeds; recent skirmishes in the seed wars. Cardozo J. Int'l \& Comp. L, 11(247).

Baer, K. W. (1995). A theory of intellectual property and the biodiversity treaty. Syracuse J. Int'l L. \& Com, 21, 259-267. 
Bhatia, S. (2018). Introduction to pharmaceutical biotechnology, Volume 1, Basic techniques and concepts. IOP Publishing Ltd.

Blakeney, M. (2004). Bioprospecting and biopiracy. In B. Ong (Ed.), Intellectual Property and Biological Resources (pp. 393-424). Marshall Cavendish Academic.

Correa, C. (2003). Establishing a disclosure of origin obligation in the TRIPs Agreement. Occasional Paper 12.

Correa, C. M. (2000). Intellectual property, the WTO and developing countries: The TRIPs agreement and policy options. Zed Books Ltd London and New York and Third World Network.

Drahos, P. (2005). The regulation of public goods. In International public goods and transfer of technology under a globalized intellectual property regime (Keith E. Maskus and Jerome H Reichman) (pp. 46-68). Cambridge University Press.

Dutfield, G. (2000). Intellectual property rights, trade and biodiversity: Seeds and plant varieties. Earthscan.

Dutfield, G. (2005). Thinking aloud on disclosure of origin. QUNO Occasional Paper 18, 2.

FisherIII, W. W. (2001). Managing genetic resources. In M. A. and W. W. F. I. Field (Ed.), Legal reform in central America; Dispute resolution and property system. Harvard Studies on International Development, Kennedy School of Government. Retrieved from http://www.law.harvard.edu/faculty/tfisher/ bioprospecting.html

Grubb, P. W. (2004). Patents for chemicals, pharmaceuticals and biotechnology: Fundamentals of global law, practice and strategy (4th ed.). Oxford University Press.

HO, C. M. (2006). Biopiracy and beyond; a consideration of sociocultural conflict with global patent policy. U. Mich. J.L., 29.

IP Australia. (2003). Australian patents for; microorganisms; cell lines; hybridomas; related biological materials and their use; \& genetically manipulated organisms, Commonwealth of Australia. Australian Government. Retrieved from http:// www.ipaustralia.gov.au/pdfs/patents/specific/biotech.pdf

Jeffry, M. I. (2004). Intellectual property rights and biodiversity conservation; reconsiling the incompatibilities of the TRIPs agreement and the convention on biological diversity. In B. Ong (Ed.), Intellectual property and biological resources, (pp. 185-225, 203). Marshall Cavendish Academic. 
Jonge, D. B. (2011). What is fair and equitable benefit-sharing.J Agric Environ Ethic, 24(127-146), 123. https://doi.org/101007/ s10806-010-9249-3

Kamau, E. C. et al. (2010). The Nagoya protocol on access to genetic resources and benefit sharing: What is new and what are the implications for provider and user countries and the scientific community? Law, Environmental and Development Journal, 6(3), 246-262,250. Retrieved from http://www.lead-journal. org/content/10246.pdf

Khor, M. (2002). Intellectual property, biodiversity and sustainable development; resolving the difficult issues. Zed Books, Third World Network.

Kunin, S. G., et al. (n.d.). Reach -through claim in the age of biotechnology. American University Law Review, 5, 609638. Retrieved from http://www.wcl.american.edu/journal/ lawrev/51/Kunin.pdf?rd=1

Llewelyn, M. (1994). Industrial applicability/utility and genetic engineering: Current practices in Europe and the United States. European Intellectual Property Review, 11, 473.

Lorenzo, V. de. (2018). How biotechnology is evolving in the fourth industrial revolution. Word Economic Forum. Retrieved from https://www.weforum.org/agenda/2018/05/biotechnologyevolve-fourth-industrial-revolution/

Maskus, K. E., \& Reichman, J. H. (2005). International public goods and transfer of technology under a globalized intellectual property regime. Cambridge University Press.

May, C., \& Sell, S, K. (2006). Intellectual property rights; a critical history. Lynne Rienners Publishers.

McCall, D. D. (2003). Stating the obvious: Patents and biological material. U. Ill. J. L. Tech. \& Pol'y.

McKeough, J. et al. (2007). Intellectual property, commentary and material (4th ed.). Law Book Co.

Mcmanis, C. R. (2004). Fitting traditional knowledge protection and biopiracy claims into the existing intellectual property and unfair competition framework (B. Ong (Ed.)). Marshall Cavendish Academic.

Medaglia, J. C. et al. (2012). Overview of national and regional measures on access to genetic resources and benefit-sharing: Challenges and opportunities in implementing the Nagoya protocol (2nd ed.). Centre for International and Sustainable Development Law. 
Merges, R. P., \& Ginsburg, J. C. (2004). Foundations of intellectual property. Foundation Press.

Mgbeoji, I. (2003). The Juridical origins of the international patent system: Towards a historiography of the role of patents in industrialization. Journal of History of International Law, 5, 403-422.

Mgbeoji, I. (2006). Global biopiracy: Patent, plants and indigenous knowledge. UBCPress.

Muller, M. R. (2018). Access to genetic resources and benefitsharing 25 Years on: Progress and challenges.iInternational Centre for Trade andsSustainable Development, 44, 44.

Najar, G. S. (2011). The Nagoya protocol on access and benefit sharing of genetic resources: Analysis and implementation options for developing countries. Research Papers, 36, 26.

NS, S. (2008). Biotechnology and patent law, patenting living beings. Manuputra.

Palombi, L. (2004). The patenting of biological materials in the context of the agreement on trade-related aspects of intellectual property rights. University of New South Wales.

Pauchard, N. (2017). Access and benefit sharing under the convention on biological diversity and its protocol: What can some numbers tell us about the effectiveness of the regulatory regime? Resources, 6(11). Retrieved from https:// doi.org/10.3390/resources6010011

Peri Bearman. (2008). The law applied contextualizing the Islamic shari'a. I.B. Tauris \& Co. Ltd.

Perrault, A., \& Olivia, M. J. (2005). ICTSD/CIEL/IDDRI/UICN/ QUNO. Dialogue on disclosure requirements; Incorporating the CBD principles in the TRIPs agreement on the road to Hong Kong (April 21-2005), 2.

Prestre, P. G. Le. (2017). Governing global biodiversity: The evolution and implementation of the convention on biological diversity (P. G. Le Prestre (ed.)). Taylor Francis.

Rabitz, F. (2015). Biopiracy after Nagoya protocol: Problem structure, regime redesaign and implementation challenges. $A$ Journal of Brazilian Political Review, 9(2), 30-53. Retrieved from https://doi.org/http://dx.doi.org/10.1590/198138212014000200010

Reichman, J. (1994). Charting the collapse of the patent-copyright di-chotomy: Premises for a restructured international intellectual property system. Cardozo Arts and Entertainment Law Journal, 13, 475-485. 
Shanmugaiah, K. (2012). The impact of TRIPs agreement on access to medicines in developing countries: Legal challenges faced by the pharmaceutical industry particularly India. Journal of Legal Studies, 3. Retrieved from http://www.uumjls.uum. edu.my/images/2012-PastIssues/3-2012.pdf

Statement by His Excellency Prime Minister $\mathrm{Dr}$ Mahathir Mohamad of Malaysia at the United Nations Conference on Environment and Development. (1992). ASEAN Economic Bulletin, 9(1). Retrieved from https://www.jstor.org/ stable/25770405?seq=1\#metadata info_tab_contents(et

The Nuffield Council on Bioethics. (2002). The ethics of patenting $D N A$. The Nuffield Council on Bioethics. Retrieved from http://http//www.nuffieldbioehics.org

Ullrich, H. (2005). Expansionist intellectual property protection and reductionist competition rules: A TRIPs perspectives. In International public goods and transfer of technology under a globalized intellectual property regime (Keith E. Maskus and Jerome H. Reichman) (pp. 709-725). Cambridge University Press.

Wahid, R., et al. (2019). Sustaining innovative education through intellectual property. UUM Journal of Legal Studies, 10(2), 79,101. Retrieved from http://www.uumjls.uum.edu.my/ images/vol10no2/79-101.pdf

WIPO. (2004). Intellectual property questions in relation to genetic resources' information meeting on intellectual property and genetic resources. Geneva. 